\title{
The Character Educators of Future: What do they know? What do they need?
}

\author{
Sarl, Mediha ${ }^{a}$ and Yolcu, Ece ${ }^{b}$
}

${ }^{\mathrm{a}}$ Department of Educational Sciences, Cukurova University, Turkey, ${ }^{\mathrm{b}}$ Department of Educational Sciences, Cukurova University, Turkey

\begin{abstract}
Providing the wholistic development of individual in terms of personal and psychological characteristics guiding our actions with educational processes forms "the character education". Teachers as an important figure in this process should be aware of character education and what they are responsible for. To achieve this, teacher education should include the essentials of character education and prepare teachers for their inevitable role within their professional life. This study aimed to reveal what the preservice primary school teachers know about character education and what their needs through their education for becoming a character educator are. The participants were preservice teachers from primary school education department in Cukurova University. The data was collected with an open ended quesitonnaire and analyzed using content analysis. According to findings, it is obvious that preservice teachers are mostly aware of the importance and content of character education and they see what their future roles are. They came up with many recommendations for teachers and teacher education. This study is thought to be beneficial in terms of revealing the situation within preservice teachers regarding character education awareness and also helping teacher educators to see what preservice teachers need to be efficient character educators.
\end{abstract}

Keywords: Character education; preservice teacher; teacher education 


\section{Introduction}

Character and its formation is a longstanding issue under debate within education. Character is the wholistic development of the individual in terms of personal and psychological characteristics guiding our actions (Berkowitz, 2002; Battistich, 2011). To provide this development by various means is called character education. Character education is a cultivation of virtue in an intentional way having three main goals: making the people, schools and society good (Lickona, 1999, p.78). The main definition for character education could be structured as to provide the holistic development of an individual including personal and psychological characteristics consisting of values such as honesty, respect, responsibility, justice, caring, citizenship with the cooperation of social institutions and creating a convenient environment (JIE, 2014; CEP, 2010). This education is getting more important and popular day by day. There are also many programs carried out to enhance this education throughout the world (such as Knowledge is Power Program [KIPP], Character First Education (cf), and Character Counts!). For instance, KIPP is a program focused on holistic development of individuals including character, knowledge, skills, habits needed for success (KIPP, 1994).

When it is asked what the responsibility teachers and schools should take through this process, there is a lot to do in terms of shaping the students' character and teachers start to share the duty of families when the school age comes. Character formation is a complex process and teachers should be patient and motivated to overcome it and to help teachers to have this capacity the relationship between teacher efficacy and character education should be detected (Milson \&Mehlig, 2002, p.48). The teachers also know the importance of character education to be a part of curriculum and it is necessary however, there is no consensus on what it is and how it should be carried out (Mathison, 1999). Having a crucial role in character education, primary school teachers were found to have a high level of selfefficacy in character education through the studies conducted (Demirel, 2009; Milson \&Mehlig, 2002). When teaching is thought as a moral issue than educating the teachers should be in the same way according to the educators (O'Sullivan, 2005, p.4). Therefore, it is necessary to include character education in teacher education programs however, generally it is not involved (Beachum, McCray, Yawn and Obiakor, 2013, p.478). Accordingly, it can be asserted that preservice teachers' knowledge regarding character education is very limited. It is very significant that the preservice teachers have the higher education to be prepared for their moral roles through students' character formation and to achieve this, the undergraduate education they receive should possess the necessary qualities. Faculties of education should make preservice teachers understand the effect of their roles in the future on character education and increase their knowledge and awareness (S1lay, 2010, p.131). It is very important to educate them with a fully equipped teacher 
education curriculum through their higher education process in which character education consists one of the biggest parts both theoretically and practically.

There are limited number of studies regarding the preservice teachers' awareness and knowledge about character education and their views on undergraduate education's role. As the character educators of future, it is very important to reveal what they know about this education and what they need through their training in higher education institutions. Accordingly, the aim of this study was "to discover preservice teachers' knowledge, awareness and recommendations about character education in their undergraduate process". Hence, their definitions for character education, descriptions for teachers' roles, views and recommendations regarding the practices of character education in undergraduate education were investigated.

\section{Method}

As its aim was to reveal the views of preservice teachers on character education, their awareness regarding this education and their recommendations through teachers' and teacher education's role within the process, a design would help to have a deep understanding was thought to be beneficial and the study was designed using qualitative phenomenological design.

The participants of the study were randomly chosen on voluntary basis 42 juniors and seniors (37 female, 5 male) from Primary School Teaching Department at Cukurova University, Adana, Turkey using the convenience sampling method. Primary school teachers are the teachers mostly in contact with children at a critical age for character formation and so more related to this study.

Through data collection, "Character Education In Teacher Education Form" prepared and conducted by the researchers was used. It included five open ended questions about their definitions for character education, descriptions for teachers' roles, views and recommendations regarding the practices of character education in undergraduate education. The questions structured and having the expert opinion the form was restructured. The final form was conducted through 2015-2016 Education year.

Content analysis was used to analyze the data and the forms were coded by two researchers separately. The codes and themes were checked by these researchers together objectively and the different codes and themes were discussed to have a consensus while the matching ones were used as they. Also the coder reliability according to formula by Miles and Huberman (1994) was found .86. Some quations were also presented to strengthen the reliability and validity of the content analysis. PT abbreviation was used to refer the preservice teachers used with a number to present the findings. 


\section{Findings}

\subsection{Findings regarding the definitions of preservice teachers for character education}

Regarding the definitions of preservice teachers for character education, it is seen that their definitions were gathered under two themes presented on Table 1.

Table 1. Findings regarding the definitions of preservice teachers for character education

\begin{tabular}{|c|c|c|}
\hline Themes & Codes & f \\
\hline \multirow{5}{*}{$\begin{array}{l}\text { The education for } \\
\text { personal and } \\
\text { behavioral } \\
\text { development (f:35) }\end{array}$} & The education shaping the personality and character & 14 \\
\hline & Having the good behavior distinguishing good and bad & 6 \\
\hline & $\begin{array}{l}\text { Providing the moral and social development and creating a } \\
\text { good person }\end{array}$ & 5 \\
\hline & Creating awareness for and know oneself & 5 \\
\hline & Educating and developing oneself & 5 \\
\hline \multirow{2}{*}{$\begin{array}{c}\text { The education for } \\
\text { providing adaptation } \\
\text { to universal and social } \\
\text { life (f:11) }\end{array}$} & Equipping with universal values & 6 \\
\hline & $\begin{array}{l}\text { Educating in line with social moral values and attitudes and } \\
\text { bringing people in confirmity with the society }\end{array}$ & 6 \\
\hline
\end{tabular}

As it is seen on Table 1, the education shaping the personality and character was the most emphasized definition by the preservice teachers for character education. One of the preservice teachers indicated the relation between character and personality as: "Character determines the personality. Character education on the other hand, is the education helping the personality shaping and presenting this personality" (PT3). The other frequent codes under the personal and behavioral development theme were having the good behavior distinguishing good and bad, providing the moral and social development and creating a good person, creating awareness for and know oneself, educating and developing one self. The other theme regarding the definitions of preservice teachers was the education for providing adaptation to universal and social life. Under this theme, one of the participants related character education with equipping with universal values and stated it as: "It is gaining the universal values will be beneficial for themselves and the society to our children" (PT39). The other codes under this theme were mostly related to the social life such as educating in line with socal moral values and attitudes and bringing people in confirmity with the society, establishing self-respect and respect for society.

\subsection{Findings regarding the descriptions for teachers' role in character education}

The preservice teachers were asked to describe the roles of teachers through character education. Findings regarding preservice teachers' views on roles of teachers were presented on Table 2. 
Table 2.Findings regarding preservice teachers' views on roles of teachers

\begin{tabular}{clc}
\hline Themes & \multicolumn{1}{c}{ Codes } & f \\
\hline \multirow{2}{*}{$\begin{array}{c}\text { The qualities } \\
\text { teachers possess } \\
\text { (f:31) }\end{array}$} & Being a model and having the ideal qualities & 17 \\
\cline { 2 - 3 } & Being leading, supportive and incentive & 12 \\
\cline { 2 - 3 } $\begin{array}{c}\text { The practices related } \\
\text { to character } \\
\text { education (f:29) }\end{array}$ & Being consistent & \multicolumn{1}{c}{ Taking charge after the family } \\
\cline { 2 - 3 } & Knowing the student and guiding his knowing and self-expression & 6 \\
\cline { 2 - 3 } & $\begin{array}{l}\text { Caring for and applying the education towards shaping the } \\
\text { character and personality }\end{array}$ & 5 \\
\cline { 2 - 3 } & Correcting the negative behaviors and gaining positive qualities & 5 \\
\cline { 2 - 3 } & Educating the students without hurting or pushing them & 5 \\
\hline
\end{tabular}

It is seen on Table 2 that the most frequent theme was the qualities teachers should possess and the most emphasized codes by the participants were being a model and having the ideal qualities and being leading, supportive and incentive under this theme. Regarding these descriptions for teachers role PT15 said: "The teacher should lead the student and be a model and guide". Another theme regarding the findings for teachers' role in character education was the expected practices related to character education and within this theme the preservice came up with roles such as taking charge after the family, knowing the student and guiding his knowing and self-expression, caring for and applying the education towards shaping the character and personality. One of the participants stressed the necessity for practices related to character education: "Teacher is the most important figure after the family in shaping student's character. Teacher should not teach anything by being angry or humiliating to the child and be patient and tolerant" (PT28). The other roles or duties of teachers were indicated as gaining universal values, gaining the awareness for hospitality, using strategies or methods such as drama, etc... and linking with the real life.

\subsection{Findings regarding the practices of character education in undergraduate education}

In this part, the participants introduced the practices regarding character education through their undergraduate studies and findings are shown on Table 3.

Table 3. Preservice Teachers' Views on Character Education Practices In Graduate Education

\begin{tabular}{|c|c|c|}
\hline Themes & Codes & $\mathbf{f}$ \\
\hline \multirow[b]{2}{*}{ Inclusion in the courses (f:13) } & Providing values education & 7 \\
\hline & $\begin{array}{l}\text { Utilizing from cases, group work, research and } \\
\text { extracurricular activities }\end{array}$ & 3 \\
\hline \multirow{2}{*}{ The qualities gained (f:3) } & Teaching how to behave and adress students & 2 \\
\hline & Making students sensitive to the society & 1 \\
\hline \multirow{2}{*}{ Extracurricular activities (f:6) } & Personal development and leadership seminars & 4 \\
\hline & General gainings of teacher education & 2 \\
\hline \multirow{3}{*}{$\begin{array}{l}\text { Deficiencies concerning the } \\
\text { practices (f:13) }\end{array}$} & No specific practices & 5 \\
\hline & Being limited to theoretical knowledge and abstract & 4 \\
\hline & Inefficient practice & 4 \\
\hline
\end{tabular}


The participants' views on character education practices in graduate education were gathered under four themes and the most frequently mentioned practice was providing values education through undergraduate education. Preservice teachers also remarked utilizing from cases, group work, research and extracurricular activities, attatinments of social studies teaching courses. PT36 examplified the practices concerning character education: "We are receiving values education. There are some extracurricular activities and they give some reserach work". Another title regarding the practices was the qualities gained regarding character education. The most emphasized one was teaching how to behave and address students. The last theme was deficiencies concerning the practices of character education and some participants indicated that there were no specific practices or inefficient practices and the character education's being limited to theoretical knowledge and abstract. Regarding these deficiencies or absence of practices PT3 stated: "I do not believe there are any applications regarding character education in our undergraduate education" and PT23 said ".... They only tell us how to act, what to do or what kind of character we should have orally”.

\subsection{Findings regarding the recommendations for character education in undergraduate education}

Findings about recommendations of participants are presented on Table 4.

Table 4. Recommendations for Character Education In Undergraduate Education

\begin{tabular}{clc}
\hline Themes & \multicolumn{1}{c}{ Codes } & f \\
\hline \multirow{3}{*}{$\begin{array}{c}\text { The quality of education } \\
\text { (f:20) }\end{array}$} & Practical education more than theoretical & 10 \\
\cline { 2 - 3 } & Including in curriculum as a course & 5 \\
\cline { 2 - 3 } & $\begin{array}{l}\text { An environment which personalities are considered in, allows } \\
\text { self-reflection and free }\end{array}$ & 5 \\
\hline \multirow{3}{*}{$\begin{array}{c}\text { The qualities to be gained } \\
\text { (f:10) }\end{array}$} & Being understanding, responsible, warm-hearted and tolerant & 4 \\
\cline { 2 - 3 } & $\begin{array}{l}\text { Making them see the students' imperfections, develop their } \\
\text { skills and guide them }\end{array}$ & 3 \\
\cline { 2 - 3 } & Gaining personal and character properties to be a role model & 3 \\
\hline
\end{tabular}

On Table 4, it can be seen that preservice teachers put forward recommendations regarding the quality of education and the qualities to be gained. Under the quality of education, the most emphasized code was practical education more than theoretical. They also came up with recommendations such as including character education as a course in the curriculum, creating an environment which personalities are considered in, allow selfreflection and free. One of the participants' advice was "There might be a course for this topic and this course should practical more than theoretical" (PT10). There were also recommendations regarding the qualities to be gained to preservice teachers for character education. One of these recommendations: "There should be an education through which I 
can reflect myself or my feelings and thoughts, respectful and tolerant. There should be curricula providing the inclusion of values we desire to be in character....." (PT22).

\section{Discussion and Conclusion}

Through the study, the participants were asked questions regarding their knowledge about character education and teachers' role through this process and their recommendations towards realizing these roles and enhancing the undergraduate education. It is found out that preservice teachers mostly know about character education and its content and they came up with the definitions above. These are very consistent with the definitions through the literature. Hoge (2002) stated that character education could be defined as the effort to contribute to individuals' having the desirable qulities or character traits. Another description for character education is that it is an intentional endavour to teach good human qualities (Lickona, 1997). By these explanations, it is revealed that preservice teachers were mostly aware of the content of this education.

The preservice teachers were seen to clear about the role teachers have through character education. In Sanger and Osguthorpe's study, it is seen that preservice teachers prefer teaching seeing it as a moral profession (2011) and this makes them feel responsible in the process. In this study, participants indicated some qualities teachers have such as being a model and having the ideal qualities and stated the practices they were expected to carry out. Similarly, while Avc1 (2011) found that teachers stresses the activities related to being a role model, preventing the wrong behaviors, creating a democratic environment, guiding students for rights and wrongs; Narvaez and Lapsley (2008) emphasized teacher should know the relationship between caring class atmosphere and character education and they need the pedagogical competencies to create these environments.

When it came to undergraduate education, participants stated what they gained through which activities but still, many of them expressed the inefficiency of character education practices. Some of them emphasized the inclusion of character education in some courses or utilizing from curricular and extracurricular activites however, others also mentioned there were not any specific practices or these practices were inefficient. Similar studies show that the teacher education programs mostly do not prepare teachers for character formation (Munson, 2000; Beachum, McCray, Yawn \& Obiakor, 2013). Regarding teacher education's role in raising character educators, the participants give some advices such as focusing on practical education, including as a course, gaining qualities such as responsibility, tolerance, creating a free environment. Munson (2000) also emphasizes teacher education programs' serving for character education to prepare preservice teachers towards the moral problems they might encounter in their classes. Based on these findings, it could be asserted that many precautions could be taken to increase the preservice teachers' awareness and efficacies regarding character education such as adding a course, 
The Character Educators of Future: What do they know? What do they need?

being practical not theoretical and using the hidden curriculum. Within all these arrangements, it could be achieved to make the preservice teachers graduate with the awareness, responsibility and equipment of being character educators of future.

\section{References}

Avc1, E. (2011). İlköğretim sosyal bilgiler öğretmenlerinin karakter eğitimine dair özyeterliklerinin incelenmesi. Yayımlanmamış doktora tezi. Gazi Üniversitesi, Ankara.

Battistich, V. (2011). Character education, prevention, and positive youth development. Retrieved October 27, 2014 from http://www.character.org/wpcontent/uploads/2011/12/White_Paper_Battistich.pdf

Beachum, F., McCray, C., Yawn, C., \& Obiakor, F. (2013). Support and importance of character education: preservice teacher perceptions. Education, 133 (4), 470-480.

Berkowitz, M., W. (2002). The science of character education. In W. Damon (Ed.), Bringing in a New Era in Character Education, (pp. 64-84). California: Hoover Institution Press.

Character Education Partnership. (2010). A framework for school success: Eleven principles of effective character education. United States of America.

Demirel, M. (2009). Sınıf öğretmenlerinin ve okul yöneticilerinin karakter eğitimine ilişkin öz-yeterlik inançları. Hacettepe Üniversitesi Eğitim Fakültesi Dergisi, 37, 36-49.

Hoge, J., D. (2002). Character education, citizenship education, and the social studies. The Social Studies, 93(3), 103-108.

Josephson Institute of Ethics. (2014). The six pillars of character. Retrieved October 31, 2014, from http://charactercounts.org/sixpillars.html

Knowledge is Power Program. (1994). Retrieved April 10, 2016, from http://www.kipp.org/about-kipp

Lickona, T. (1997). The teacher's role in character education. Journal of Education, 179 (2), 63-80.

Lickona, T. (1999). Character education: Seven crucial issues. Action in Teacher Education, 20 (4), 77-84.

Mathison, C. (1999). How teachers feel about character education: A descriptive study. Action in Teacher Education, 20 (4), 29-38.

Milson, A., J. \& Mehlig, L., M. (2002). Elementary school teachers' sense of efficacy for character education. The Journal of Educational Research, 96 (1), 47-53.

Munson, B. R. (2000). Character education: The missing ingredient of preservice teacher education programs. Paper presented at the Annual Meeting of the American Association of Colleges for Teacher Education (52nd,Chicago, February 26-29, 2000).

Narvaez, D. \& Lapsley, D. K. (2008). Teaching moral character: Two alternatives for teacher education. The Teacher Educator, 43 (2), 156-172.

O'sullivan, S. (2005). The soul of teaching: Educating teachers of character. Action in Teacher Education, 26 (4), 3-9.

Sanger, M., N. \& Osguthorpe, R., D. (2011). Teacher education, preservice teacher beliefs, and the moral work of teaching. Teaching and Teacher Education, 27, 569-578.

Sılay, N. (2009). Yükseköğretimde karakter ĕgitiminin incelenmesi. Yayımlanmış doktora tezi, Marmara Üniversitesi Eğitim Bilimleri Enstitüsü, İstanbul. 